\title{
MODULUS ELASTISITAS DAN KEKUATAN LENTUR BALOK KAYU LAMINASI
}

\author{
Fengky S. Yoresta ${ }^{1}$
}

\begin{abstract}
ABSTRAK
Penelitian ini dilakukan untuk menentukan pengaruh penggunaan paku dan perekat serta diameter paku terhadap Modulus Elastisitas (MOE) dan kekuatan lentur (MOR) balok kayu laminasi. Pengujian lentur dilakukan dengan metode pembebanan terpusat di tengah bentang (one-point loading method). Hasil penelitian menunjukkan bahwa posisi penempatan paku dan perekat tidak berpengaruh signifikan terhadap nilai MOR balok, akan tetapi memiliki pengaruh signifikan terhadap nilai MOE. Selain itu, diameter paku tidak berpengaruh signifikan baik terhadap nilai MOE maupun MOR.
\end{abstract}

Kata kunci : balok laminasi, MOE, MOR, paku, perekat

\section{PENDAHULUAN}

Balok kayu laminasi adalah salah satu produk rekayasa yang diciptakan untuk meningkatkan kualitas kayu struktural. Balok laminasi terdiri dari beberapa lapisan kayu yang disusun sedemikian rupa sehingga membentuk suatu kesatuan lamina. Selain menggunakan perekat antar lapisan kayu, balok laminasi juga bisa menggunakan baut atau paku sebagai penghubung antar lapisan. Pada balok laminasi baut, baut akan berfungsi sebagai transfer geser antar lamina (Pranata et al. 2012). Demikian juga hal nya pada balok laminasi paku, paku akan mentransfer geser antar lamina.

Balok laminasi paku dapat dibuat dengan mudah terutama ketika menghadapi situasi darurat di lapangan seperti setelah terjadi bencana alam. Penelitian mengenai balok laminasi mekanik paku serta kombinasinya dengan perekat belum banyak diteliti dan dikembangkan di Indoneisa. Oleh karena itu penelitian ini sangat perlu dilakukan. Tujuan dari penelitian ini adalah untuk menentukan pengaruh penggunaan paku dan perekat serta diameter paku terhadap Modulus Elastisitas dan kekuatan lentur balok kayu laminasi.

\section{METODE PENELITIAN}

\subsection{Waktu dan Tempat Penelitian}

Penelitian dilakukan di laboratorium Rekayasa dan Desain Bangunan Kayu, Departemen Hasil Hutan, Institut Pertanian Bogor (IPB). Penelitian ini dilakukan selama 3 bulan, mulai dari Juli hingga September 2014.

\footnotetext{
${ }^{I}$ Bagian Rekayasa dan Desain Bangunan Kayu, Departemen Teknologi Hasil Hutan, Institut Pertanian Bogor syfengky@gmail.com
} 


\subsection{Bahan dan Alat}

Bahan baku yang digunakan dalam penelitian ini adalah kayu Mahoni yang diperoleh dari toko bangunan di daerah Bogor, Jawa Barat. Selain itu digunakan perekat dan 2 tipe paku - paku 3" dan 4" ( $\$ 3.4 \mathrm{~mm}$ dan $\phi 4.2 \mathrm{~mm}$ ) - sebagai penghubung antar lapisan kayu. Peralatan yang digunakan terdiri dari gergaji, meteran, amplas, dan alat uji mekanik.

\subsection{Pembuatan Benda Uji}

Kayu yang akan digunakan terbebas dari cacat misalnya retak, mata kayu, dan sebagainya. Kayu tersebut dipotong dalam arah yang sejajar terhadap arah serat kayu menjadi lapisan-lapisan kayu dengan ketebalan 16,7 $\mathrm{mm}$ dan 16,6 mm. Lapisan-lapisan kayu ini digunakan sebagai penyusun balok laminasi.

Balok terdiri dari 3 lapisan kayu Mahoni yang telah dipotong dengan ketebalan lapisan atas, tengah, dan bawah berturut-turut adalah 16,6 $\mathrm{mm}, 16,7 \mathrm{~mm}$, dan 16,7 mm. Balok memiliki dimensi penampang melintang $5 \times 5 \mathrm{~cm}$ dan panjang $100 \mathrm{~cm}$. Total seluruh balok berjumlah 18 buah. Balok dibedakan menjadi tiga tipe (tipe $\mathrm{A}, \mathrm{B}$, dan $\mathrm{C}$ ). Masing-masing tipe balok menggunakan 2 tipe paku, yaitu paku 3" dan 4". Setiap tipe balok dengan diameter paku yang berbeda terdiri dari tiga sampel uji.

Balok Tipe A, B, dan C dibedakan berdasar posisi penempatan perekat dan paku. Tipe $\mathrm{C}$ hanya menggunakan paku sebagai penghubung antar laipsan kayu penyusun balok, sementara Tipe B dan A menggunakan gabungan antara perekat dan paku. Pada balok tipe C, paku ditempatkan disetiap jarak $5 \mathrm{~cm}$ disepanjang balok tersebut. Balok tipe ini sama sekali tidak menggunakan perekat untuk menghubungkan lapisan kayu. Balok tipe A menggunakan paku, dengan jarak yang sama dengan tipe $\mathrm{C}$, disepenjang $30 \mathrm{~cm}$ di tengah bentang balok dan menggunakan perekat di selain area tersebut. Sedangkan balok tipe B adalah kebalikan dari balok tipe A, paku ditempatkan di sepanjang area yang menggunakan perekat pada balok tipe $\mathrm{A}$ (kedua ujung balok) dan perekat ditempatkan di area yang menggunakan paku (30 $\mathrm{cm}$ di tengah-tengah bagian balok).

\subsection{Pengujian Lentur}

Pengujian lentur balok dilakukan menggunakan Universal Testing Mechine (UTM) merk Instron berkapasitas 5 ton. Pengujian dilakukan dengan metode pembebanan terpusat di tengah bentang (one-point loading), dimana panjang bentang pengujian adalah $90 \mathrm{~cm}$. Kadar air kayu pada saat pengujian adalah $12 \%$. Skema pengujian diperlihatkan pada Gambar 1.

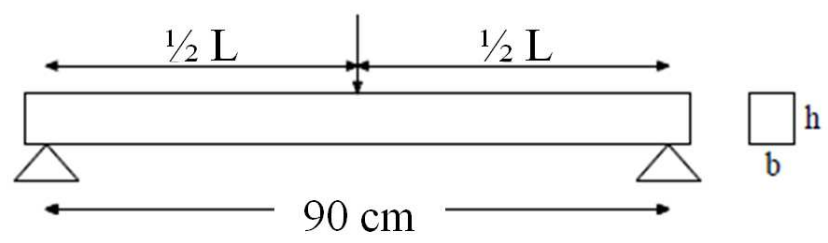

Gambar 1 Skema pengujian lentur balok

\subsection{Analisis Data}

Data hasil pengujian lentur dianalisa menggunakan metode analisis varian dua arah (two-way ANOVA) dengan tingkat kepercayaan 95\% 


\section{HASIL DAN PEMBAHASAN}

\subsection{Modulus Elastisitas (MOE)}

Modulus Elastisitas (MOE) menggambarkan ketahanan terhadap lentur, yang berhubungan langsung dengan kekakuan (Akhtari et al. 2012). Nilai ini dihitung dengan menggunakan persamaan (1) berikut, dimana $\mathrm{P}$ adalah beban $(\mathrm{kg})$; $\mathrm{L}$ adalah panjang bentang pengujian balok $(\mathrm{cm}) ; \Delta$ adalah defleksi $(\mathrm{cm})$; serta $\mathrm{b}$ dan h berturut-turut adalah lebar $(\mathrm{cm})$ dan tinggi balok $(\mathrm{cm})$

$$
\mathrm{MOE}=\left(\mathrm{PL}^{3}\right) /\left(4 \Delta \mathrm{bh}^{3}\right)
$$

Nilai MOE rata-rata balok tipe A, B, dan C diperlihatkan pada Gambar 2. Dari gambar tersebut dapat dilihat bahwa - untuk kedua tipe paku $(\phi 3.4 \mathrm{~mm}$ dan $\phi 4.2 \mathrm{~mm})$ yang digunakan - nilai MOE tertinggi terdapat pada balok tipe $\mathrm{C}\left(49864.7 \mathrm{~kg} / \mathrm{cm}^{2}\right.$ dan $\left.47784.3 \mathrm{~kg} / \mathrm{cm}^{2}\right)$, kemudian diikuti oleh balok tipe B $\left(20444.7 \mathrm{~kg} / \mathrm{cm}^{2}\right.$ dan $\left.19966.5 \mathrm{~kg} / \mathrm{cm}^{2}\right)$, sedangkan nilai terendah terdapat pada balok Tipe A $\left(8800.9 \mathrm{~kg} / \mathrm{cm}^{2}\right.$ dan $\left.12541.8 \mathrm{~kg} / \mathrm{cm}^{2}\right)$. Nilai MOE yang tinggi pada balok tipe C diduga disebabkan oleh adanya pengaruh ketahanan geser yang kuat pada balok ini sehingga mampu memperkecil deformasi geser yang terjadi. Rendahnya kekakuan lentur suatu balok sangat disebabkan oleh deformasi geser yang besar (Gotou et al. 2014). Pada penelitian ini, diameter paku tidak berpengaruh signifikan terhadap nilai MOE $(\mathrm{p}>0.05)$. Namun sebaliknya, penggunaan dan posisi penempatan paku dan perekat (tipe balok) berpengaruh signifikan terhadap nilai MOE ( $\mathrm{p}$ $0.05)$.

\subsection{Modulus of Rupture (MOR)}

Kekuatan lentur atau sering dikenal dengan istilah Modulus of Rupture (MOR) menentukan kapasitas beban eksternal yang mampu dipikul oleh sebuah balok. Nilai ini dihitung dengan menggunakan persamaan (2), dimana $\mathrm{P}$ adalah beban $(\mathrm{kg})$; $\mathrm{L}$ adalah panjang bentang pengujian balok $(\mathrm{cm})$; serta $\mathrm{b}$ dan $\mathrm{h}$ berturut-turut adalah lebar $(\mathrm{cm})$ dan tinggi balok $(\mathrm{cm})$. Nilai MOR ratarata untuk balok tipe A, B, dan C diperlihatkan pada Gambar 3.

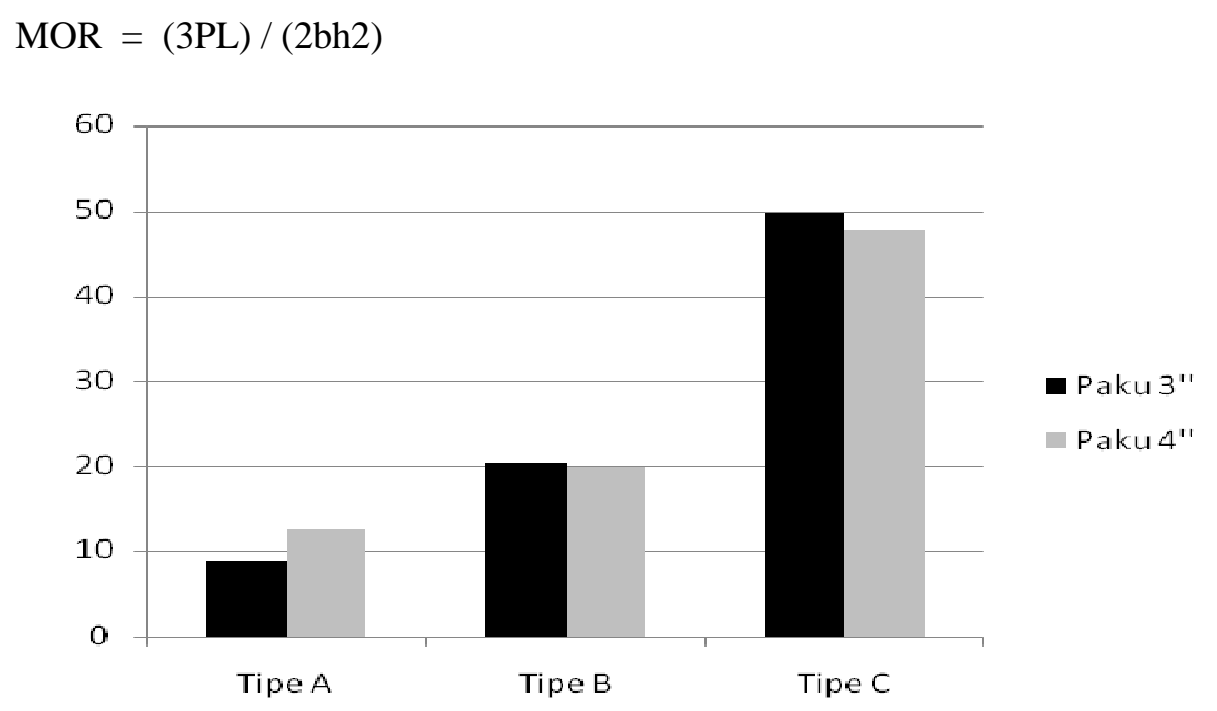

Gambar 2 Modulus Elastisitas (MOE)

Pada penelitian ini, baik diameter paku maupun tipe balok (posisi penempatan paku dan perekat pada balok) tidak berpengaruh signifikan terhadap nilai MOR ( $p>0.05)$. Nilai MOR balok yang 
menggunakan paku berdiameter $\phi 3.4 \mathrm{~mm}$ (paku 3") untuk tipe A, B, dan C berturut-turut adalah $288.5 \mathrm{~kg} / \mathrm{cm}^{2}, 301.4 \mathrm{~kg} / \mathrm{cm}^{2}$, dan $368.2 \mathrm{~kg} / \mathrm{cm}^{2}$ sedangkan untuk balok yang menggunakan paku berdiameter $\phi 4.2 \mathrm{~mm}$ (paku 4") adalah $298.9 \mathrm{~kg} / \mathrm{cm}^{2}, 356.9 \mathrm{~kg} / \mathrm{cm}^{2}$, dan $350.8 \mathrm{~kg} / \mathrm{cm}^{2}$. Kekuatan lentur maksimum balok laminasi akan semakin kecil apabila terjadi kerusakan slip antar lapisan penyusunnya (Sulistyawati et al. 2008). Kerusakan ini sangat mungkin terjadi di area yang menggunakan perekat sebagai penghubung karena kekuatan geser perekat lebih kecil dari paku. Hal ini terjadi apabila rekatan antar lapisan kayu kurang sempurna (Yoresta 2014) sehingga balok tidak berperilaku sebagai satu kesatuan.

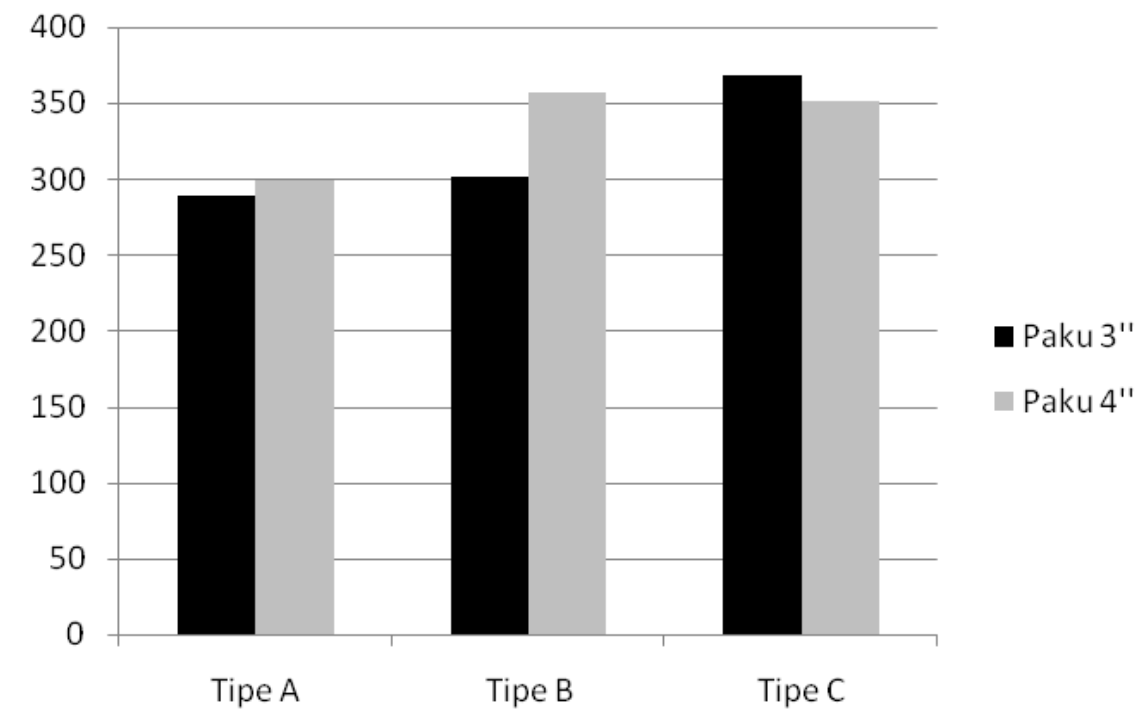

Gambar 3 Modulus of Rupture (MOR)

\section{KESIMPULAN}

Berdasarkan hasil temuan dalam penelitian ini dapat disimpulkan bahwa posisi penempatan paku dan perekat tidak memberikan pengaruh signifikan terhadap nilai MOR balok, akan tetapi berpengaruh signifikan terhadap nilai MOE. Selain itu, diameter paku tidak berpengaruh signifikan baik terhadap nilai MOE maupun MOR. Nilai MOE dan MOR tertinggi terdapat pada balok tipe C yang menggunakan paku berdiameter $\phi 3.4 \mathrm{~mm}$, yaitu berturut-turut sebesar $49864.7 \mathrm{~kg} / \mathrm{cm}^{2}$ dan $368.2 \mathrm{~kg} / \mathrm{cm}^{2}$.

\section{DAFTAR KEPUSTAKAAN}

Akhtari M, Kokandeh MG, \& Taghiyari HR. 2012. Mechanical properties of paulownia fortunei wood impregnated with Silver, Copper and Zinc Oxide Nanoparticles. Journal of Tropical Forest Science 24(4): 507-511.

Gotou H, Hiroshi T, Takanobu S, Yasushi H, \& Chiaki W. 2014. Shear behavior of on-site timber stresslaminated Box-beam bridges. Proceedings of World Conference on Timber Engineering WCTE. Canada.

Pranata YA, Bambang S, \& Johannes AT. 2012. Rasio modulus penampang elastik balok kayu laminasi-baut. Jurnal Teknik Sipil 19(3):223-236.

Sulistyawati I, Naresworo N, Surjono S, \& Yusuf SH. 2008. Kekakuan dan kekuatan lentur maksimum balok glulam dan utuh kayu akasia. Jurnal Teknik Sipil 15(3):113-122.

Yoresta FS. 2014. Studi Eksperimental Perilaku Lentur Balok Glulam Kayu Pinus (Pinus merkusii). Jurnal Ilmu dan Teknologi Kayu Tropis 12(1):33-38. 